\title{
EDUCATION OF TOLERANCE OF PRESCHOOL CHILDREN WITH RESPECT TO CHILDREN WITH SPECIAL EDUCATIONAL NEEDS Nekrasova O.A. ${ }^{1}$, Chuikova I.V. ${ }^{2}$ (Russian Federation) Email: Nekrasova329@scientifictext.ru
}

\author{
${ }^{I}$ Nekrasova Olga Alexsandrovna - PhD in of pedagogical sciences, Associate Professor; \\ ${ }^{2}$ Chuikova Irina Vladimirovna-PhD in of pedagogical sciences, Associate Professor, \\ DEPARTMENT OF PEDAGOGICAL AND SPECIAL EDUCATION, \\ SURGUT STATE PEDAGOGICAL UNIVERSITY, \\ SURGUT
}

\begin{abstract}
: in the article the necessity of formation of tolerant attitudes of preschoolers toward children with special needs in the inclusive education, as preschool education is the initial stage in the moral development of the child. Highlights the results of a research aimed at studying the level of formation of tolerant attitudes of preschoolers toward children with special needs. The features of the organization of work on formation of tolerant relations in children of preschool age as the main component organization of the inclusive educational environment.
\end{abstract}

Keywords: preschool children, children with special needs, inclusion, inclusive education, tolerance, coeducation, tolerant attitude.

\section{ВОСПИТАНИЕ ТОЛЕРАНТНОСТИ ДОШКОЛЬНИКОВ ПО ОТНОШЕНИЮ К ДЕТЯМ С ОСОБЫМИ ОБРАЗОВАТЕЛЬНЫМИ ПОТРЕБНОСТЯМИ Некрасова О.А. ${ }^{1}$, Чуйкова И.В. ${ }^{2}$ (Российская Федерация)}

\author{
${ }^{1}$ Некрасова Ольга Александровна - кандидат педагогических наук, доцент, \\ ${ }^{2}$ Чуйкова Ирина Владимировна - кандидат педагогических наук, дочент, \\ кафедра педагогического и специиального образования, \\ Сургутский государственный педагогический университет, \\ 2. Cургут
}

\begin{abstract}
Аннотация: в статье отражена необходимость формирования толерантного отношения дошкольников к детям с особыми потребностями в условиях инклюзивного образования, так как именно дошкольное образование и воспитание являются начальным этапом в нравственном развитии ребенка. Освещзаются результаты исследования, направленные на изучение уровня сформированности толерантного отношения дошкольников $\kappa$ детям $c$ особыми потребностями. Рассматриваются особенности организации работы по формированию толерантного отношения у детей дошкольного возраста как основного компонента организаџии инклюзивной образовательной средыл.
\end{abstract}

Ключевые слова: дошкольники, дети с особыми потребностями, инклюзия, инклюзивное образование, толерантность, совместное образование, толерантное отношение.

В последние годы в России развивается процесс инклюзии детей с особыми потребностями в общеобразовательную среду вместе с нормально развивающимися сверстниками. В Федеральном законе «Об образовании в РФ» № 273-Ф3 от 29.12.12 закреплены положения об инклюзивном, то есть совместном обучении и воспитании детей с особыми потребностями: «В целях реализации права каждого человека на образование федеральными государственными органами, органами государственной власти субъектов Российской Федерации и органами местного самоуправления создаются необходимые условия для получения без дискриминации качественного образования лицами с ограниченными возможностями здоровья, для коррекции нарушений развития и социальной адаптации, оказания ранней коррекционной помощи на основе специальных педагогических подходов и наиболее подходящих для этих лиц языков, методов и способов общения и условия, в максимальной степени способствующие получению образования определенного уровня и определенной направленности, а также социальному развитию этих лиц, в том числе посредством организации инклюзивного образования лиц с ограниченными возможностями здоровья». Образование обучающихся с особыми потребностями может быть организовано совместно с другими обучающимися, не имеющих психофизических отклонений [5, с. 135].

Активное внедрение инклюзивного образования актуализирует необходимость целенаправленного формирования в обществе толерантного отношения к людям с особыми потребностями, что является основой эффективного совместного взаимоотношения между детьми.

Проблема формирования толерантности не является новой. Среди ученых, внесших вклад в изучение проблем толерантности в России, - А.Г. Асмолов, изучавший подходы к определению понятия 
«толерантность», В.Л. Лекторский, выделявший различные критерии толерантности как этического феномена, В.В. Шалин, рассматривавший место толерантности в системе либеральных ценностей, А.А. Гусейнов, Д.В. Зиновьев, П.Ф. Комогоров, А.А. Реан, В.А. Ситаров, П.Ф. Степанов и др. рассматривают толерантность как сформированное моральное качество, моральная добродетель, родовое существенное свойство человека, условие успешной социализации, проявляющееся в социальных отношениях, главным признаком которого является уважение права другого на отличие, В.В. Бойко, рассматривающий «коммуникативную толерантность» [1, с. 150].

За рубежом проблемами толерантности занимаются П. Николсон, рассматривавший толерантность как моральный идеал, М. Уолцер, предложивший выделять различные степени проявления толерантности личности, Дж. Роле, исследовавший толерантность как моральную добродетель в рамках своей теории справедливости, Б.З. Вульф отмечает феномен толерантности как - способности человека (или группы) сосуществовать с другими людьми (сообществами), которым присущи иные менталитет, образ жизни и др. [3, с. 84].

Особое внимание приобретает проблема формирования толерантного отношения дошкольников к детям с особыми потребностями, так как именно дошкольное образование и воспитание является начальным этапом в нравственном развитии ребенка. Но, к сожалению, как показывает практика, многие дети, не имеющие психофизических отклонений, не готовы принять детей с особыми потребностями [2, c. 267].

Данный факт подтверждается и в результате проведенного нами исследования, которое имело цель изучить уровень сформированности у дошкольников толерантного отношения к детям с особыми потребностями. Исследование проводилось среди детей дошкольного возраста образовательных учреждений г. Сургута, Сургутского района. Всего в исследовании принимали участие 113 человек [4, с. 24].

По результатам исследования можно сказать, что только $20 \%$ детей имеют достаточно полные представления о детях с ОВЗ. Они хорошо информированы о правилах поведения в обществе таких детей, стараются понять их эмоции и желания; проявляют интерес к взаимодействию с ними, хотят оказать им помощь, проявляют по отношению к ним заботу, сочувствие, сострадание, понимают и откликаются на чувства и эмоции детей с особыми потребностями, выражают желание делиться с ними игрушками, позитивно относятся к проявлению различных потребностей детей, обусловленных ОВ3.

Большинство детей: $65 \%$ детей показали средний уровень сформированности толерантного отношения к детям с ОВ3. Эти дети имеют фрагментарные представления о детях с ОВ3. Они мало информированы о правилах поведения с такими детьми, лишь частично понимают их эмоции и желания, проявляют фрагментарный интерес к взаимодействию. Кроме того, у них не появляется желания помогать таким детям, готовность к выстраиванию взаимоотношений с такими детьми нестабильна и, скорее всего, будут помогать и делиться игрушками не по собственной инициативе и не с особым желанием, а по просьбе либо взрослого, либо самого ребенка с особыми потребностями.

$15 \%$ детей имеют низкий уровень. У детей данной категории не сформированы представления о детях с особыми потребностями. Они не информированы о правилах поведения в обществе таких детей, не понимают их эмоции и желания. Отсутствует интерес и желания вступать с ними в контакт. Эти дети не готовы к выстраиванию взаимоотношений с детьми с особыми потребностями.

Таким образом, подводя итоги можно, сделать вывод, что результаты исследования показали низкий уровень сформированности у дошкольников толерантного отношения к детям с особыми потребностями. Это говорит о том, что необходимо начинать формирование толерантного отношения к детям с особыми потребностями именно с дошкольного возраста. В дошкольном возрасте у ребенка формируются начальные моральные ценности, нормы поведения, формируются представления о важности человеческого достоинства, происходит осознание ценности своей личности и окружающих людей, воспитывается уважение к ним, чувство солидарности и желание сотрудничества с ними, умение разрешать конфликтные ситуации ненасильственным путем. Кроме того, дошкольник имеет пластичную нервную систему, он активно познает различные знания об окружающем мире, способы его познания, начинает активно усваивать ценности общества, знакомится с социальными ролями. Поэтому именно дошкольному образованию и воспитанию должна быть отведена решающая роль в реализации задач формирования толерантного отношения (Ш. Амонашвили, Л.С. Выготский, А.В. Запорожец, Н.Н. Поддъяков) [7, с. 115].

Одной из основных задач работников ДОО является - научить детей дошкольного возраста толерантно относиться друг к другу. При этом важно не только передать необходимую информации о многообразии и отличиях людей в мире, об особенностях детей с особыми потребностями, их возможностях и ограничениях, о помощи, которая им требуется, но и сформировать у дошкольников умения анализировать свои собственные поступки, осознавать, что от поведения каждого из них зависит многое. Кроме этого детям необходимо показать пути противостояния насилию, жестокости, несправедливости, как и в какой форме можно не допустить этого. Встать на чью-либо сторону, 
защитить интересы не только свои, если возникает такая необходимость, помочь, проявить сочувствие, сопереживание.

Эта задача выполнима при условии хорошо организованной работы и приложении достаточных усилий со стороны всех участников образовательного процесса. Работа должна быть систематической и планомерной, строиться с учетом возрастных и индивидуальных особенностей детей. Материал интересный и разнообразный, с использованием инновационных технологий и методик. Целесообразна интеграция с содержанием занятий по изобразительной, театрализованной деятельности, познавательному, речевому, физическому развитию, игровой деятельности.

В работе по формированию толерантности предполагает создание в коллективе спокойной, благоприятной, доброжелательной обстановки, большого уважения к личности ребенка, максимального использования своих возможностей и опыта других педагогов.

Важное значение имеет и предупреждение возникновения психотравмирующих ситуаций в системе межличностных отношений: ребенок с нарушениями развития - обычные сверстники; родители ребенка с нарушениями развития - педагог; родители ребенка с нарушениями развития - родители обычных детей. Поэтому необходимо системно и планомерно выстраивать работу по формированию толерантных отношений между субъектами инклюзивного образования [6, с. 14].

Особую роль несет в себе и тесное сотрудничество с родителями, что в свою очередь помогает выработать единый стиль в работе. Ведь значение семьи в формировании толерантного сознания и поведения ребенка трудно переоценить. Родители являются первыми и главными воспитателями детей. Поэтому, если в решении этой проблемы родители не будут помогать педагогам, то сформировать у ребенка толерантность, как и любое другое морально-нравственное качество, будет очень сложно или невозможно.

В семье ребенок получает главный опыт взаимодействия с людьми, в ней ребенок получает уроки общения, осваивает приемы коммуникации, учится принимать мнение окружающих, с уважением относиться к своим близким. Личный пример родителей, родственников играет важную роль в освоении опыта толерантного поведения. Большое влияние на формирование толерантного отношения оказывают атмосфера отношений в семье, стиль взаимодействия между родителями, родственниками, детьми. Семья во многом может помочь ДОО.

Таким образом, проблема толерантного отношения является общей как для педагогов, так и для родителей. Формирование его необходимо начинать именно с дошкольного возраста, когда у ребенка только начинают развиваться моральные ценности, нормы поведения, создаются представления о важности человеческого достоинства, происходит осознание ценности своей личности и окружающих людей, воспитывается уважение к ним, чувство солидарности и желание сотрудничества с ними, умение разрешать конфликтные ситуации ненасильственным путем.

\section{Сиисок литературы / References}

1. Асмолов А.Г. Толерантность: различные парадигмы анализа [Текст] // Толерантность в общественном сознании России. М. : Смысл, 1998. 246 с.

2. Гусейнова Э.М. Основные подходы к изучению понятия толерантности в отечественной и зарубежной науке [Текст] // Молодой ученый, 2014. № 21. С. 626-629.

3. Колесникова О.А. Витагенный опыт как средство умственного развития дошкольников [Текст] // дис. ... канд. пед. наук. Екатеринбург, 2002. 185.

4. Коротовских Т.В., Чуйкова И.В., Некрасова О.А. Изучение уровня сформированности толерантного отношения дошкольников к детям с ОВ3 в условиях инклюзивного образования// Глобальный научный потенциал, 2017. № 1 (70). С. 21-25.

5. Некрасова О.А., Чуйкова И.В. Психологическая готовность как результат подготовки будущего педагога дошкольной образовательной организации к профессиональной деятельности [Текст] // European Social Science Journal, 2015. № 4. C. 134-138.

6. Овсянникова O.A. Формирование толерантного отношения дошкольников к сверстникам средствами искусства [Текст] // автореф. дис. ... канд. пед. наук. Екатеринбург, 2003. 28 с.

7. Поддубная И.В., Зеленина Е.И. Формирование толерантности у детей дошкольного возраста в условиях образовательного учреждения [Текст] // Личность, семья и общество: вопросы педагогики и психологии: сб. ст. по матер. XV междунар. науч.-практ. конф. Часть II. Новосибирск: СибАК, 2012. 